\title{
SURGICAL TREATMENT OF RECURRENT METASTATIC PARATHYROID GLAND CARCINOMA
}

\author{
Zaviša Čolović, Mladen Krnić ${ }^{2}$, Zlatko Kljajići , Mirko Kontić $^{1}$, \\ Nikola Kolja Poljak ${ }^{1}$, Robert Tafra ${ }^{1}$ and Petar Ivanišević ${ }^{1}$
}

${ }^{1}$ University of Split, Split University Hospital Center, Department of Otorhinolaryngology, Split, Croatia; ${ }^{2}$ University of Split, Split University Hospital Center, Department of Endocrinology, Split, Croatia

\begin{abstract}
SUMMARY - Aim: We present the case of a 48-year-old male patient who underwent surgery for a recurrent metastatic parathyroid gland carcinoma in the patient's right paratracheal space of the neck. The patient had undergone surgery for lower right parathyroid gland carcinoma 28 months earlier. Results: The metastases were resected en bloc with an ipsilateral central neck dissection and with the removal of the enlarged lower left parathyroid gland. After exploration of the remnant parathyroid glands we noticed that lower left parathyroid gland was macroscopically enlarged so we decided to remove it to prevent possible hypercalcemia in future and to also prevent possible recurrence of cancer or development of a new primary, considering the identical embryological origin of the lower parathyroid glands and possibility of synchronous, multiple tumors, which generally follow the same embryological origin if they occur. The patient was also treated with radiation therapy after the surgery. Conclusion: With the present surgical approach to recurrent metastatic parathyroid gland carcinoma, we aimed to prevent the recurrence of cancer or development of new primary and prevent or delay hypercalcemia in the future with all severe adverse metabolic states associated with high serum calcium levels.
\end{abstract}

Key words: recurrent metastatic parathyroid gland carcinoma, embryological origin, surgical treatment

\section{Introduction}

During embryonic development, the upper parathyroid glands develop from the fourth pharyngeal pouch, and the lower parathyroid glands develop from the third pharyngeal pouch.

Parathyroid gland cancer is rare and accounts for less than $1 \%$ of all of the illnesses that affect the parathyroid glands ${ }^{1,2}$. The incidence of parathyroid gland cancer is 0.5 to $4.0 \%$ in cases of hyperparathyroidism ${ }^{3,4}$.

Parathyroid carcinoma is one of the rarest among malignant tumors, with a ratio of $0.005 \%$ among all malignant tumours ${ }^{5}$.

Corresponding author: Dr. Petar Ivanišević, MD, University of Split, University Hospital Center Split, Department of Otorhinolaryngology, Split, Croatia, Spinčićeva 1, 21000 Split, Croatia

E-mail: pivanisevic@kbsplit.hr
$90 \%$ of parathyroid gland carcinoma are hormonally functional, with most patients presenting with hypercalcemia as the initial manifestation of the disease ${ }^{6}$.

The diagnosis and management of parathyroid gland carcinoma is difficult. Clinically it should be suspected preoperatively if any of these conditions are present: severe hypercalcemia, very high PTH levels ( $>5$ times the normal level), hypercalcemia associated with cervical mass, or vocal cord paralysis ${ }^{7}$.

Non-functioning parathyroid gland carcinomas (less than 10\%) usually present at a more advanced stage with symptoms of compression/invasion of adjacent structures, neck mass and/or dysphagia, hoarseness, or dyspnea ${ }^{6}$.

Lymph node and distant metastases at the time of diagnosis are uncommon, occurring in 1-6\% and 2-4\% cases, respectively ${ }^{6}$.

About half of the patients experience a relapse 2 to 5 years after the initial resection, usually presenting 
with slowly increasing serum calcium and PTH levels in functioning parathyroid gland carcinomas ${ }^{6}$.

Disease progression is usually marked mainly by the clinical manifestation of hypercalcemia and its related complications ${ }^{6}$.

The disease-free interval to the appearance of metastatic disease may be up to 20 years ${ }^{6}$.

Recurrence is typically regional, which accounts for approximately two thirds of relapses. Approximately half of the patients with recurrence also present distant metastases with the most common sites being in the lungs (40\%), liver (10\%) and, very rarely, in the bones, pleura, pericardium, and pancreas ${ }^{6}$.

Imaging studies are generally useful for preoperative localization of the diseased glands in primary hyperparathyroidism. Ultrasound (US) and technetium Tc $99 \mathrm{~m}$ sestamibi scanning have a sensitivity of $65 \%$ and $80 \%$, respectively, in detecting diseased glands ${ }^{8}$. US is effective in localizing local metastases, especially those involving neck lymph nodes, while a MIBI scan can detect both local and distant metastases, which may also be visible on CT and MRI. Both CT and MRI may provide information about lesion extension and eventual invasion into surrounding structures, lymph nodes, or distant metastasis; CT usually shows low sensitivity in detecting parathyroid gland carcinoma, while MRI is also adequate for soft tissue imaging. Few studies are available on the use of $18 \mathrm{~F}$-fluorodeoxyglucose positron emission tomography (FDG PET), aimed at early identification of metastases/recurrence ${ }^{6}$.

Frozen section analysis is not helpfu1 ${ }^{9}$.

Intraoperative findings are important for establishing the appropriate diagnosis of parathyroid gland carcinoma. The gland's firmness, large size, grayish white color, and adherence to surrounding soft tissues should raise the suspicion of carcinoma. However, even at expert institutions with experienced surgeons, up to $86 \%$ of parathyroid carcinoma is not recognized by surgeons intraoperatively ${ }^{10}$.

Reported surgical interventions fall into two main categories: en bloc resection and local-only excision ${ }^{6}$.

The most common therapy for parathyroid gland cancer is surgery, most authors concur that en bloc excision at initial surgery which includes the removal of the affected parathyroid gland/resection of the tumor with an ipsilateral thyroid lobectomy and resection of adjacent cervical muscles, paratracheal lymphatic tis- sue, and any contiguous tissue to which the tumor adheres reduces the need for repeat surgery and improves survival outcomes.

A selective or a radical neck dissection may be performed in case of metastases to the neck, depending on the extent of the spread of the metastasis ${ }^{1,6,11-13}$.

There is no clear evidence that performing prophylactic central or lateral neck dissections may improve survival. On the other hand, central neck dissection has been proposed at the first surgical approach in all patients with parathyroid gland carcinoma, on the basis that the central compartment has been involved in up to $10 \%$ of cases and that omitting central and/or ipsilateral jugular compartment dissection might carry a 1.5 to 2.0 times higher risk of both 5 -year recurrence and death ${ }^{6}$.

In a retrospective series, aggressive surgical resection of recurrent disease has been associated with up to a 30\% increase in long-term survival ${ }^{6}$.

Although parathyroid gland tumors are not sensitive to radiation therapy (RT), RT has been used to improve local control and to reduce the possibility of local recurrence ${ }^{14-16}$.

Non-surgical therapies for parathyroid gland carcinoma generally have poor results. Chemotherapy is usually ineffective. The results of RT are also usually non-satisfactory, but some investigators have nevertheless supported use of RT to improve on local recurrence rates and overall survival in small series ${ }^{6}$.

Single case reports have provided some evidence that anti-PTH immunotherapy may help prolonged control of hypercalcemia unresponsive to conventional treatments and control tumor growth, achieving reduction of metastatic tumor burden in some cases ${ }^{6}$.

Overall survival rates for parathyroid gland carcinoma are generally better than in most solid tumors with 76 to $85 \%$ and 49 to $77 \%$ patients surviving, respectively, at 5-year and 10-year follow up ${ }^{6}$.

Cancer-related death in the functional cancers it is usually due to renal failure, cardiac arrhythmias, or pancreatitis resulting from uncontrollable hypercalcemia, while cancer-related death in non-functional parathyroid gland cancer is primarily due to the burden of regional disease and to distant metastases ${ }^{6}$.

\section{Case report}

A 48-year-old male patient was hospitalized in the ENT clinic at the Split University Hospital for the 
second time in January 2009, 28 months after undergoing surgery for the removal of a cancerous lower right parathyroid gland. The lower right parathyroid gland was removed during his first hospitalization in August 2006 in the ENT clinic at the Split University Hospital. Four weeks later, after a biopsy confirmed

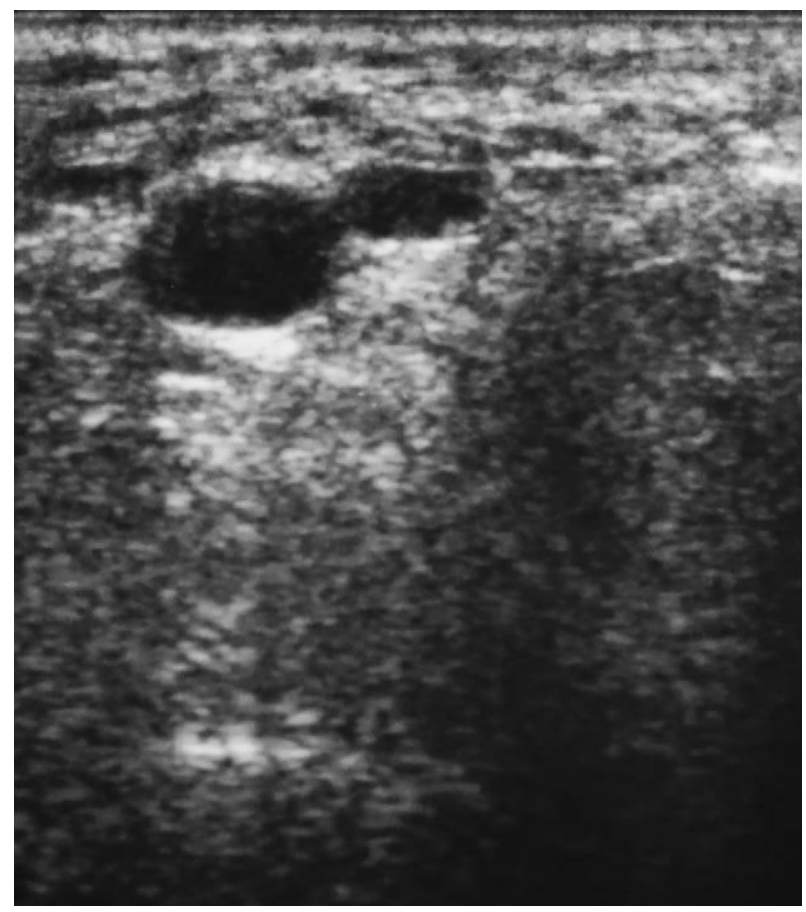

Figure 1. Ultrasound of the neck.

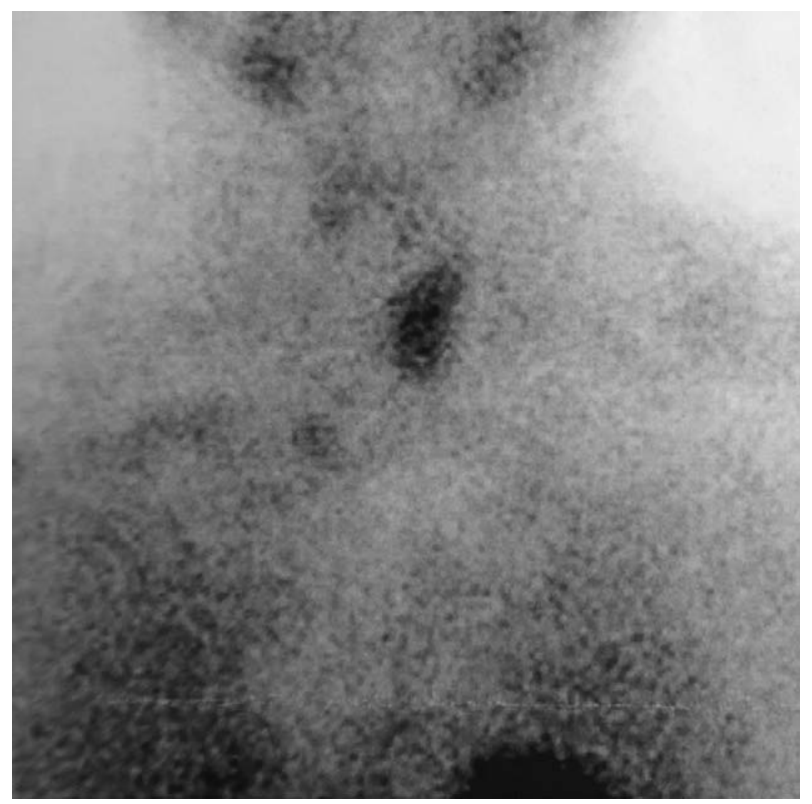

the appearance of cancer of the lower right parathyroid gland, a right-side ipsilateral lobectomy of thyroid gland was performed. A lateral neck dissection was also performed, although preoperative US of the neck did not find neck metastases (the exact type of lateral neck dissection is unclear because the operation was performed by another otorhinolaryngologist and medical documentation about it was not precise). Central neck dissection was not performed, according to previous medical documentation. The histopathological findings from the right thyroid lobe and lateral neck dissected tissue were negative.

In January 2009, 28 months after the first hospitalization, the patient was hospitalized again due to hypercalcemia and a suspicion of cancer recurrence.

On admission, the patient's blood calcium level was $3.5 \mathrm{mmol} / \mathrm{L}(2.14-2.53 \mathrm{mmol} / \mathrm{L})$ and PTH level was $254 \mathrm{pg} / \mathrm{mL}$ (15-65 pg/mL). An ultrasound of the neck revealed two hypoechogenic cervical masse in the right paratracheal space of the neck (Figure 1). The size of the larger cervical masses was $11 \times 8 \times 12 \mathrm{~mm}$, and the size of the smaller cervical masses was $6 \times 4 \times 6 \mathrm{~mm}$. A fine needle aspiration (FNA) confirmed carcinoma primarily from the previous parathyroid gland cancer. Scintigraphy of the parathyroid glands with $99 \mathrm{mTc}-$ MIBI at 15 and 120 minutes after the radioisotope injection revealed focal activities in the scans that corresponded to the metastatic activity in the right para-

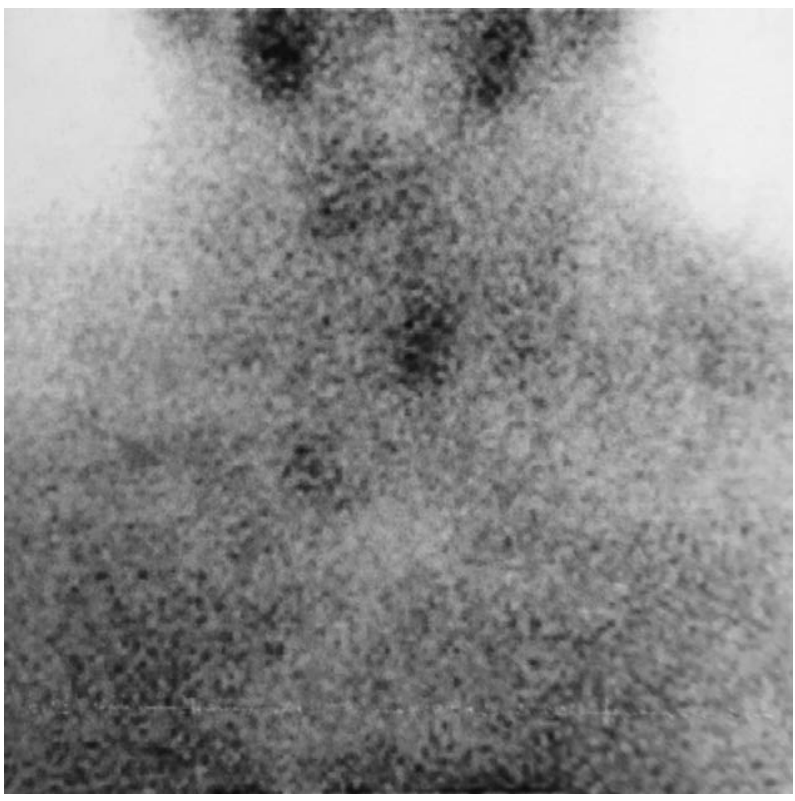

Figure 2. Scintigraphy of the parathyroid glands. 
tracheal space of the neck (Figure 2). MSCT and MRI of the neck were also performed. We also evaluated and excluded distant metastases prior to surgery by performing a complete body FDG PET scan.

The metastatic tumors were resected en bloc with an ipsilateral central neck dissection. The other remnant parathyroid glands were concurrently examined. After exploration of the remaining parathyroid glands, we noticed that lower left parathyroid gland was macroscopically enlarged so we decided to remove it to prevent possible future hypercalcemia and to also prevent possible recurrence of cancer or development of a new primary cancer, considering the identical embryological origin of the lower parathyroid glands and considering the possibility of synchronous, multiglandular parathyroid gland tumors, which in most cases follow the same embryological origin if they occur. We were also guided by the fact that one preserved parathyroid gland is known to be sufficient to maintain normal blood calcium levels.

Pathohistological analysis confirmed that the two metastatic tumors and lower left parathyroid gland were completely removed. However, this parathyroid gland was normal and did not appear to be affected by cancer or adenoma. Postoperative recovery was optimal but included transient hypocalcemia, which resulted in the administration of peroral Calcitriol capsules and calcium supplementation ${ }^{17}$. Soon after the surgery, the patient's calcium level normalized without any therapy.

The patient was also treated with adjuvant radiation therapy, which began approximately four weeks after the surgery. More than 11 years after the surgery, there were no signs of cancer recurrence, and the blood calcium level was within normal levels without any therapy.

\section{Discussion}

After reviewing the surgical treatment options for recurring metastatic carcinoma of the parathyroid glands, we found a wide range of approaches from relatively conservative surgeries with a limited resection of affected tissue to more radical surgery approaches.

In our case, the metastases were resected en bloc with an ipsilateral central neck dissection. After explo- ration of the remaining parathyroid glands, we noticed that the lower left parathyroid gland was macroscopically enlarged, so we decided to remove it to prevent possible hypercalcemia in future and to also prevent possible recurrence of cancer or development of a new primary cancer, considering the identical embryological origin of the lower parathyroid glands and possibility of synchronous, multiglandular tumors, which mostly follow the same embryological origin if they occur. We were also guided by the fact that one preserved parathyroid gland is known to be sufficient to maintain normal blood calcium levels.

According to Attie et al., multiple enlarged parathyroid glands have been reported in $1.7 \%$ to $8.5 \%$ of primary hyperparathyroidism cases $^{18}$.

Multiglandular parathyroid carcinoma is an extremely rare entity.

There are few cases of simultaneous, synchronous multiglandular appearance of parathyroid glands carcinoma, which occur mostly in parathyroid glands according to embryological origin reported in the English literature ${ }^{19-21}$.

Kameyama and Takami reported a case of a 67-year-old man who had double parathyroid glands carcinoma of the upper left and right parathyroid glands. Surgery was performed using an intraoperative quick intact $\mathrm{PTH}$ assay $(\mathrm{QPTH})^{19}$.

Intra-operative PTH levels can fall significantly after parathyroid gland carcinoma resection, although often not as quickly as with benign disease ${ }^{6}$.

Brown et al. described a case of a 51-year-old man who had high levels of serum calcium and parathyroid hormone. Only three parathyroid glands could be identified during surgery; the left superior gland could not be located and was presumed to have been removed during thyroid lobectomy in the past, 11 years ago. Both inferior parathyroid glands (left and right) were grossly enlarged and exhibited some adherence to the surrounding soft tissues. The decision was made to remove both enlarged inferior parathyroid glands and leave the remnant of the thyroid gland in place. Malignancy was not suspected nor confirmed by frozen section at the time of surgery. Definitive histopathologic findings led to a diagnosis of parathyroid carcinoma of both inferior glands. Three weeks later, the patient underwent a completion thyroidectomy en block with anterior neck dissection, which detected no evidence of residual parathyroid carcinoma ${ }^{20}$. 
Haciyanli et al. presented a case of simultaneous bilateral and multiglandular parathyroid glands carcinoma in a 48-year-old woman presenting with primary hyperparathyroidism. She was treated with bilateral neck exploration and parathyroidectomy of the right lower gland with en block resection of the adjacent thyroid lobe and parathyroidectomy of the left lower gland with resection of surrounding soft tissue.

In this case, the authors emphasized that bilateral neck exploration and identification of all 4 glands in select cases of parathyroid carcinoma should be considered if there is concrete evidence of a second tumor, since parathyroid carcinoma can be multiglandular or coexist with adenoma or hyperplasia of other glands ${ }^{21}$.

\section{Conclusion}

The surgical approach in the present case was aimed toward a prophylactic approach reducing the possibility of cancer recurrence or development of new one, taking into account the publications mentioned above that indicate possible synchronous, multiglandular tumors that mainly follow the same embryological basis. In the present case, we were also guided by our understanding that the treatment for recurrent metastatic disease is often directed toward controlling hypercalcemia ${ }^{22}$. Although our experience in managing parathyroid carcinoma is limited because of its rarity, with the presented surgical approach we aimed to prevent or delay possible recurrent hypercalcemia in the future and to control the severe adverse metabolic states associated with high serum calcium levels in these patients, as well as to prevent possible tumor recurrence and/or development of a new primary tumor. Further multicentric studies are needed to standardize treatment of recurrent/metastatic parathyroid gland carcinoma.

\section{References}

1. Rao SR, Shaha AR, Singh B, Rinaldo A, Ferlito A. Management of cancer of the parathyroid. Acta Otolaryngol. 2002; 122:448-52. 10.1080.00016.480260000184.

2. Shaha AR, Shah JP. Parathyroid carcinoma: a diagnostic and therapeutic challenge. Cancer. 1999;86:378-80. 10.1002/ (SICI)1097-0142.

3. Babar-Craig H, Quaglia A, Stearns M. Parathyroid carcinoma: a report of two cases and a concise review and update of the literature. J Laryngol Otol. 2005;119:577-80. 10.1258/ 0022215054352261 .
4. Chiofalo MG, Scognamiglio F, Losito S, Lastoria S, Marone U, Pezzullo L. Huge parathyroid carcinoma: Clinical considerations and literature review. World J Surg Oncol. 2005;3:39. 10.1186/1477-7819-3-39.

5. Kusić Z, Prgomet D. Tumori šitnjače i doštitne žlijezde. In: Prgomet. Tumori glave i vrata. Zagreb: Medicinska naklada; 2019. p. 262-277.

6. Ferraro V, Sgaramella LI, Di Meo G, Prete FP, Logoluso F, Minerva F, Noviello M, Renzulli G, Gurrdao A, Testini M. Current concepts in parathyroid carcinoma: a single Centre experience. BMC Endocr Disord. 2019;19(Suppl 1):46. doi: 10.1186/s12902-019-0386-1.

7. Lee JE. Predicting the presence of parathyroid carcinoma. Ann Surg Oncol. 2005;12:513-14. 10.1245/ASO.2005.03.904.

8. Arici C, Cheah WK, Ituarte PH, Morita E, Lynch TC, Siperstein $\mathrm{AE}$ et al. Can localization studies be used to direct focused parathyroid operations? Surgery. 2001;129:720-29. 10.1067/msy.2001.114556.

9. Fernandez-Ranvier GG, Khanafshar E, Jensen K, Jensen K, Zarnegar R, Lee J et al. Parathyroid carcinoma, atypical parathyroid adenoma, or parathyromatosis? Cancer. 2007;110: 255-264. 10.1002/cncr.22790.

10. Sahasranam P, Tran MT, Mohamed H, Friedman TC. Multiglandular parathyroid carcinoma: a case report and brief review. South Med J. 2007;100:841-44.

11. Montenegro FL, Tavares MR, Durazzo MD, Cernea CR, Cordeiro AC, Ferraz AR. Clinical suspicion and parathyroid carcinoma management. Sao Paulo Med J. 2006;124:42-4.10.1590/ S-1516-31802006000100009.

12. Dudney WC, Bodenner D, Stack BD Jr. Parathyroid carcinoma. Otolaryngol Clin North Am. 2010;43:441-53. 10.1016/j. otc.2010.01.011.

13. Givi B, Shah JP. Parathyroid carcinoma. Clin Oncol (R Coll Radiol). 2010;22:498-507. 10.1016/j.clon.2010.04.007.

14. Clayman GL, Gonzalez HE, EL-Naggar AK, VassilopoulouSellin R. Parathyroid carcinoma: evaluation and interdisciplinary management Cancer. 2004;100:900-5.10.1002/cner.20089.

15. Busaidy NL, Jimenez C, Habra MA, Schultz PN, EL-Naggar AK, Clayman GL et al. Parathyroid carcinoma: a 22-year experience. Head Neck. 2004;26:716-26. 10.1002/hed.20049.

16. Lee JE. Predicting the presence of parathyroid carcinoma. Ann Surg Oncol. 2005;12:513-4. 10.1245/ASO.2005.03.904.

17. Curic Radivojevic R, Prgomet D, Markesic J, Ezgeta C. Hypocalcaemia after thyroid surgery for differentiated thyroid carcinoma: preliminary study report. Coll Antropol. 2012;36 (Supp12):73-8.

18. Attie JN, Bock G, Auguste LJ.Multiple parathyroid adenomas: report of thirty-trhee cases. Surgery. 1990;108:1014-19.

19. Kameyama K, Takami H, Endocr J. Double parathyroid. Carcinoma. 2003;50:477-9. 10.1507/endocrj.50.477.

20. Brown JJ, Mohamed H, Williams-Smith L, Osborne R, Coker J, Yee B. Primary hyperparathyroidism secondary to simultaneous bilateral parathyroid carcinoma. Ear Nose Throat J. 2002; 81:395-8, 400-1. 
21. Haciyanli M, Oruk G, Ucarsoy AA, Gur O, Genc H. Multiglandular parathyroid carcinoma: case report and review of the literature. Endocr Pract. 2011;17:79-83. 10.4158/EP11037.CRR.
22. Owen RP, Silver CE, Pelliteri PK, Shaha AR, Devaney KO, Werner JA et al. Parathyroid carcinoma: a review. Head Neck. 2011;33:429-36. 10.1002/hed.21376.

Sažetak

\title{
KIRURŠKO LIJEČENJE RECIDIVIRAJUĆEG METASTATSKOG KARCINOMA DOŠTITNE ŽLIJEZDE
}

\author{
Z. Čolovic, M. Krnic, Z. Kljajic, M. Kontic, N. Kolja Poljak, R. Tafra i P. Ivanišević
}

Cilj: Prikaz slučaja 48 godišnjeg muškog bolesnika koji je operiran zbog recidvirajućeg metastatskog karcinoma doštitne žlijezde u paratrahealnom prostoru vrata desno. 28 mjeseci prije bolesnik je operiran poradi karcinoma donje desne doštitne žlijezde. Rezultati: Metastaze su odstranjene zajedno s ipsilateralnom centralnom disekcijom desne strane vrata kao i povećana donja lijeva doštitna žlijezda. Naime, nakon eksploracije preostalih doštitnih žlijezda, primjetili smo da je donja lijeva doštitna žlijezda makroskopski povećana, pa smo je odlučili odstraniti zbog te činjenice te da preveniramo razvoj moguće hiperkalcemije u budućnosti, a također i da preveniramo mogući recidiv karcinoma ili razvoj novog primarnog karcinoma uzimajući u obzir istu embriološku osnovu nastanka donjih doštitnih žlijezda i mogućnost razvoja istodobnih, sinhronih karcinoma doštitnih žlijezda koji, ukoliko se pojave, uglavnom prate istu embriološku osnovu. Bolesnik je liječen i radioterapijom nakon operacije. Zaključak: Prikazanim kirurškim pristupom liječenju recidivirajućeg metastatskog karcinoma doštitne žlijezde cilj nam je bio da spriječimo ponovni recidiv karcinoma ili nastanak novog primarnog karcinoma i da spriječimo ili odgodimo razvoj moguće hiperkalcemije u budućnosti sa svim teškim štetnim metaboličkim stanjima povezanima s visokim razinama kalcija u serumu.

Ključne riječi: recidivirajući metastatski karcinom doštitne žlijezde, embriološka osnova, kirurško liječenje 